\title{
Increasing Students' Learning Motivation Through Android-Base Biology Educational Game with E-Module During COVID-19 Pandemic
}

\author{
Elvara Aroyandini ${ }^{1, *}$ Suyitno Aloysius ${ }^{2}$ \\ ${ }^{1}$ Master of Biology Education, Faculty of Mathematics and Natural Sciences, Universitas Negeri Yogyakarta, \\ Indonesia \\ ${ }^{2}$ Department of Biology Education, Faculty of Mathematics and Natural Sciences, Universitas Negeri \\ Yogyakarta, Indonesia \\ *Corresponding author. Email: elvaranorma.2019@students.uny.ac.id
}

\begin{abstract}
The aim of the research is to increase students' learning motivation in learning classification of living things subject by using android-based biology educational game that accompanied with e-module. The type of this reserach is is a quasi-experiment research with nonequivalent control group design that concluded in at SMP N 3 Sragen, Central Java. The population of this study were the grade VII students of SMP N 3 Sragen in 2020/2021 academic year with the students of VII A class as the experimental class and the students of VII B class as the control class. Instrument that uses in this research is questionnaire. The control class only using google form as the learning medium, while the experimental class using google form that added by android-base biology educational game with e-module. The result shows that students learning motivations in the experimental class from 76,18 to 90,23, while in control class also increase from 74,73 to 82,14 . Therefore, it can be concluded that the use of androidbase biology educational game with e-module during the COVID-19 pandemic can increase students' learning motivation better than using google form only.
\end{abstract}

Keywords: Educational game, E-module, Motivation, COVID-19 pandemic

\section{INTRODUCTION}

Education in Indonesia faces many problems, they are problems from students, teachers, facilitates, and many others. These problems make the aims of education difficult to reach, especially in this pandemic situation that require students to study from their home. In this different situation, teachers can't deliver material to students directly. The teachers have difficulties in controlling students' spirit because they just meet in the virtual room. This situation makes students' motivation decrease. Previously research informs that $52,6 \%$ from 344 students say that their motivations decrease during this online learning [1].

This situation is also found in SMP N 3 Sragen. Base on the interview with the biology teacher, students of SMP N 3 Sragen's motivation during the COVID-19 pandemic decrease. The indicators are students lazy to read the material, they do the task perfunctorily and then collect the task to the teacher, and they don't finish the task although they have adequate equipment. Interview to some students also inform that they bore very much and less motivation when study at home. Indeed, they want to study at the classroom immediately. But, because of the cases of COVID-19 in Indonesia always increase day by day, so the online-learning is still the best choice to do.

This abnormal situation demands the teacher to always give the best learning process for their students in order to preserve the students' motivation to study. Weinstein and McCombs identifiy that students' motivation is one of three academic learning's important component, except skill and self-regulation. Self-regulation also the component which students can control their knowledge and motivation during learning [2]. Because of that, increasing of students' motivation in learning accordance with the increase of students' learning outcome [3], where reduced motivation makes the students' learning outcome drop [4]. It accordance with the recent researches which inform that students' motivation affect their learning outcome [5-7]. If the students are motivated, they are 
interested to learn [8] and work hard to learn more [7]. This is in accordance with Zaharah which say that increasing of students' motivation also increase their learning outcome. It is evidenced with the quantity of students that reach the minimum score that increase from $27 \%$ to $86.7 \%$ [6].

Teacher must keep the students' motivation to study, such as by making learning media that estimated can increase the students' motivation in learning [8]. But, because of the lack of time, teacher just use Google Form as the learning medium to study about nature science, especially in the classification of living things subject that present in grade VII, Junior High School. Except Google Form, tearcher also using Google Classroom and WhatsApp as the learning media, but the using of both media is not effective. These both media is just using to send the link of the Google Form, so the students' primer media is only Google For. The effective use of Google Form actually is to assess the students' learning outcomes, while the learning process is held in Google Classroom like had done by Bekti Mulatsih in SMA N 1 Banguntapan [9]. But, because in SMP N 3 Sragen much students difficult to access both media, so the teacher still using Google Form as the primer medium. The using of Google Form as learning medium in this pandemic situation is the part of teachers professionalism which teacher try to adapt with this different situation. Using Google Form also better than not using any medium, because Google Form has many benefits like can add texts, pictures, and videos as the learning medium that can easy accessed by the students [10].

In spite of that, the researchers asume that using other medium except Google Form is better. Therefore, the researhers choose educational game as a learning medium that estimeted can makes students more motivated to study. Research that done by Assa Prima Sekarini conclude that $81,9 \%$ students from two school that researched said that they interested in using educational game as a learning media in the subject of natural science. The teachers of the schools is also agree with it, because they think that using educational game can increase students' motivation and learning outcome, specially in natural science [11]. Other research also conclude that educational game makes learning process more interesting, so it will be also increase students' motiviation [12]. Educational game also helps students to understand the material with the increase of students' score is $40,45 \%$, from $33,65 \%$ to $74,13 \%$ in the living things subject, specifically in the reptil class unit [13].

The educational game that developed also accompanied by electronic-module (e-module). The aim of inserting e-module into the android application is to make students not just playing the games, but also studied about the material. Recent studies conclude that using electronic module is very effective to increase students' motivation significantly. It is because e-module makes the learning medium more concrete and attractive, so the student more enjoy to study with that learning medium [6].

The educational game and e-module is packed in the mobile application that students can acces it by android phone. This form makes students easier to open it in every time and everywhere. So, students can study about the material whenever they want [14]. Moreover, in this pandemic situation that students not study at the class, this form makes the teacher easier to send it to all of the students. This product is also economical, because to use it the students just need to download it from internet and than install and use it in their smartphone. This learning media is also paperless because students must not pay for the printed papers like in the print form. In addition, research done by Jeno also conclude that using mobile application intrinsically more motivating than using printed textbook [15].

The material topic in this learning medium is about living thing classification. This material is the difficult material in the students and moreover in the teachers' perspective. It is appropriate with Insani's research which say that 13 (thirteen) from 48 (forty eight) teachers of natural science in Malang City $(27,1 \%)$ who are the members of MGMP IPA of Malang City say that classification of living things material is the most difficult topic material in science learning [16]. In the students perspective, this material is one of the difficult material to learn, because in this material there is much of latin term that unfamiliar in students daily language [17].

In this digital era, android-base smartphone developed rapidly and almost every people have this gadget. Using this medium in this era which all of the students have smartphone is very potential. It is because the students have the adequate equipment, that is android-base smartphone, so the learning process that use android smartphone is easy to do [14]. Moreover, the installation of this medium just need a few mobile data because the size of this medium is just $21 \mathrm{MB}$, or maybe also didn't need any mobile data or Wi-Fi because this medium can share from one android phone to others by application sender like ShareIt aplication. After that, the medium can use offline. The offline mode can increase the use opprtunities [18].

Because of the estimeted benefits of the learning medium that developed before, so this research applied the learning medium in the classroom to see its effectiveness to increase students' motivation in learning about classification of living things. 


\section{METHODS}

\subsection{Time and Location}

This research was conducted 2020 at SMP N 3 Sragen, located in Dr. Sutomo Street, Number 2, Kebayan 1, Sragen Kulon, Sragen District, Sragen Regency, Central Java, Indonesia 57213 in August. SMP N 3 Sragen was one of the school that its students' motivation decreased during the COVID-19 pandemic.

\subsection{Research Design}

This research is a quasi-experiment research with nonequivalent control group design. The population of this study was the grade VII students of SMP N 3 Sragen in 2020/2021 academic year. The research sample consisted of one experimental class and one control class that not randomly selected. These two classes get the same treatment using google form, but in the experimental class added by the media of android-based game education with e-module [19].

\subsection{Data Collection and Analysis}

Data were collected by questionnaires. Before biology learning was begun, students were given a learning motivation questionnaire that using a Likert scale to find out the initial motivation before learning begins (pretest). After that, all students of VII A and $\mathrm{B}$ class run the learning process in three times meeting by google form. But, in the VII A as an experimental class, teacher uses android-based biology educational game with e-module as the other resource of learning medium. In the last meeting of the living things material, all the sample members give the questionnaires to see the difference of students' learning motivation between before and after learning. The questionnaires arranged using the indicators of ARCS model that can be seen in table 1 .

Table 1. The indicator of ARCS model of motivation that use in this research

\begin{tabular}{|l|l|l|}
\hline \multicolumn{1}{|c|}{ Aspect } & \multicolumn{1}{|c|}{ Indicator } & \multicolumn{1}{|c|}{$\begin{array}{c}\text { Total } \\
\text { Item }\end{array}$} \\
\hline A (Attention) & $\begin{array}{l}\text { Perseverance and full- } \\
\text { attention in learning }\end{array}$ & 5 \\
\hline R (Revelance) & $\begin{array}{l}\text { Relate the material with } \\
\text { life }\end{array}$ & 3 \\
\hline C (Confidence) & Not easy to give up & 5 \\
\cline { 2 - 3 } & \begin{tabular}{l} 
Study independently \\
\cline { 2 - 3 }
\end{tabular} & $\begin{array}{l}\text { Be sure with self } \\
\text { abilities }\end{array}$ \\
\hline \multirow{2}{*}{ S (Satisfaction) } & $\begin{array}{l}\text { Feel happy with the } \\
\text { material studied }\end{array}$ & 7 \\
\cline { 2 - 3 } & $\begin{array}{l}\text { Satisfaction with the } \\
\text { result obtained }\end{array}$ & 2 \\
\hline Total Question & & $\mathbf{3 0}$ \\
\hline
\end{tabular}

The research design can be seen in Table 2 [19].

Table 2. Pretest-posttest control-group design

\begin{tabular}{|c|l|c|}
\hline Class & Pretest & Treatment \\
\hline Experiment & $\mathrm{Y}_{1.1}$ & $\mathrm{X}_{1}$ \\
\hline Control & $\mathrm{Y}_{1.2}$ & $\mathrm{X}_{2}$ \\
\hline Explanation: & \\
Y1.1 and Y1.2 & $:$ & Pretest \\
Y2.1 and Y2.2 & $:$ & Posttest \\
X1 & $:$ & Use Google Form and android-based \\
X2 & iology educational game with e-module \\
& Use Google Form only
\end{tabular}

The increasing of students' learning motivation is determined by the normalized gain equation below:

Normalized Gain score $(\mathrm{g})=\frac{\text { posttest score-pretest score }}{\text { maximum score-pretest score }}$

The gain score is used to determine the level of achievement of students learning motivation through and without android-based biology educational game with e-module. Table of $\mathrm{N}$-Gain score motivation category can be seen in Table 3 [27].

Table 3. N-Gain score motivation category

\begin{tabular}{|l|l|}
\hline \multicolumn{1}{|c|}{$\begin{array}{c}\text { Normalized Gain } \\
\text { Score }\end{array}$} & \multicolumn{1}{c|}{ Level } \\
\hline $\mathrm{g}>0.71$ & High \\
\hline $0.31<\mathrm{g}<0.70$ & Medium \\
\hline $\mathrm{g}<0.30$ & Low \\
\hline
\end{tabular}

The increase of students' learning motivation between the experimental class and the control class analysed using independent-sample t-test. Before that, two prerequisite test that must be fulfilled, they are the normality test and the homogeneity test. To find out this t-test and its prerequisite, statistical tests were carried out with the SPSS 16 for Windows program with $95 \%$ confidence level. It is the hypothesis of this research :

$\mathrm{H}_{0}$ : There is no significant difference in increasing learning motivation between the control and the experimental class

$\mathrm{H}_{1}$ : There is a significant difference in increasing learning motivation between the control and the experimental class

\section{RESULTS AND DISCUSSION}

The aim of the research is to increase students' learning motivation in learning biology by using android-based biology educational game with emodule. This research was conducted at SMP N 3 Sragen, Central Java with the population is all the students of grade VII, and the sample is the students of 
class VII A as experimental class and VII B as control class. Because of the COVID-19 pandemic, learning process in the classroom was changed by online learning. The science teacher of SMP N 3 Sragen chooses google form as his online media learning. He makes different learning medium every meeting and he shares the link of the google form to his students. After the students learn and understand with the material, students will do the task that follow the material and send the answer to the teacher.

The android-base biology educational game with e-module is the research product that has very good qualification as a learning media. This product has been validated by material expert, media expert, peer reviewers, and school biology teacher which said that this learning medium has very good quality with the ideal percentage is $95,14 \%$. This medium also get the responses from junior high school students and they said that the medium is very good with the ideal percentage is $100 \%$. All the respondents said that the learning medium that developed is valid and can used by teacher to teach living things classification material in the junior high school as the learning medium that makes students interested and motivated to study. So, this medium is applicated in the school to evidence it.

This android-base biology educational game with e-module has two major components, they are educational game and e-module. These two major components are linked each other. The educational game has six levels of the game and the e-module has six parts of material. Before students play the game, students must learn the e-module before, so the students will play the game with good performance and they will get the good score and medal. But if the students did not study the e-module, they will can't good score and medal because they can't do the game well. It's because the educational game will give negative score if the students choose the wrong answer. So, they must study the material first before they playing the game.

This medium makes students more motivated to study about classification of living things. The descriptive statistic about the result is shown in table 4 below.

Table 4. The descriptive statistic of the result

\begin{tabular}{|l|l|l|l|l|l|l|}
\hline Class & N & Max. & Min. & Ave-rage & Std. Dev \\
\hline \multirow{2}{*}{ Experi-mental Class } & Pre-test & 22 & 93 & 52 & 76.2 & 11.79 \\
\cline { 2 - 7 } & Post-test & 22 & 98 & 82 & 90.2 & 5.15 \\
\hline \multirow{2}{*}{ Control Class } & Pre-test & 22 & 85 & 56 & 74.7 & 8.42 \\
\cline { 2 - 7 } & Post-test & 22 & 98 & 58 & 82.1 & 9.05 \\
\hline
\end{tabular}

Based on table 4, it can be seen that the gain (increase of score) of students' learning motivation score in the sxperimental class is 14,05 while in the control class is 7,41 . It shows that students in the experimental class that uses google form and androidbase biology educational game with e-module are more motivated than students in the control class that only use google form. This data is collected by learning motivation questionnaire instrument that given before and after experiment. This questionnaire was developed based on the ARCS model of motivation. This model is used to know about students' motivation that consist of four interrelated phases for stimulating and sustaining the students' learning motivation. The four interrelated phase is Attention that refer to students interest in learning, Relevance that refer to increasing of students motivation if the learning use the examples aand languange that they familiar with, Confidence that refer to students' mind to reach their success, and Satisfaction which refer to the students' satisfied about their achievement [20].

Base on the students' questionnaire, there is different result between pretest and posttest. In pretest, students' learning motivation is low, both in experimental or control class. The indicator are they not interested to study; don't understand the material, so they difficult to relate the material with the real daily life; less confidence; easy to give up when they get problems; study when there is command drom students to study; and the others, but the posttest shows the better result both in experimental or control classes. The difference of them is the students' total number and the increase of the motivation intensity of experimental class is more than the control class. The motivation of all students of experimental class increase, while in control class, the motivation of many students is constant or precisely decrease.

However, to find out that there are significant differences between the experimental class and the control class, an independent-sample-t-test is needed. Before it, there is prerequisite test for homogeneity and normality test. The normality test shows that the Sig. (2-tailed) of normality test is ,450 (more than $, 050)$, so the data is normally distributed. Its mean that the prequisite of normality test was fullfilled. After that, we must to analysed the data homogeneity as the second prerequisite test. The result of homogeneity 
test shows that the Sig. is , 112 (more than 0,05 ), so the data is homogene. Because the data is homogene and normally distributed, so the next analysis is use
Independent-Sample T-Test for equality of means which the result is shown in Table 5 below.

Table 5. The result of independent-sample T-Test

\begin{tabular}{|l|l|l|l|l|}
\hline Test Data & Df & Sig. & Conclusion & Means \\
\hline $\begin{array}{l}t \text {-test for equality of } \\
\text { means }\end{array}$ & 42 & 0.001 & $\begin{array}{l}\mathrm{H}_{1} \text { is accepted or } \mathrm{H}_{0} \\
\text { is rejected }\end{array}$ & $\begin{array}{l}\text { There are significant differences in } \\
\text { increasing learning motivation between the } \\
\text { control and experimental class }\end{array}$ \\
\hline
\end{tabular}

In table 5 , it can be seen that sig. value of $t$-test for equality of means is $0,001(\mathrm{t}=3,643$, sig. $<0,05)$. It means that there are significant differences in increasing learning motivation which the increase of students' learning motivation in experimental class is more significant than in the control class. It means that using Google Form that accompanied by learning medium like educational game makes students more motivated than using Google Form only.

Besides, the data also analysed using the $\mathrm{N}$-gain score to determine the level of students learning motivation. Based on the range measurement of $\mathrm{N}$ gain that appears in table 3 above, it is known that the |students' motivation level both in experimental class and control class is in the medium level because the $\mathrm{g}$ is more than 0,31 . But, the $\mathrm{N}$-gain score of the experimental class is higher than the control class. The $\mathrm{N}$-gain of the experimental class is 0,64 and the control class is 0,32 or the half of experimental class' $\mathrm{N}$-gain.

The low increase of students' motivation in control class is because the learning medium that use is less attractive. This medium doesn't have reward that will students get if they done the task, there is no deduction of the score if the students choose the wrong answer. While if students use the educational game with emodule, students will more attractive to study. It is because the students challenged to always choose the right answers in order to get the best score and medal that give in the end of the game. This challenge makes students must precede cognitive thinking to overcome the target to get the best player. At the same time, students also learn about knowledge skill by learning the material and also the interaction skill [21].

The students also more enjoy, appeal, and satisfy to study with the educational game [3]. It is because in this learning medium there is music background that makes students not bore when study the material. The screen display of the medium is also interesting and full of colour and picture that accordance with the material, so the students easier to understand the material. It means that with the educational game, the students more engaged and absorbed with the learning material that insert in the game [22], than just use
Google Form medium which the students just read the material and then do the task that follow it.

Except the benefits of the game, this learning medium also get the benefits from e-module. Emodule in this learning medium arranged in such a way, so it makes students easier to understand the classification of living things material. It is because emodule allows for the display of images, audios, animations, and also videos that makes students' motivated to study, so the students' understanding becomes clearer [23]. It is because much of the biology objects specially in classification of living things material is very small. They can visualized with the images or videos, so the learning material become more concrete [6]. Using e-module also enhance the student's focus in study because all of the material is packed in the one medium [24].

This learning medium that packed in the mobile application that can access by android mobile is very useful, specially in this pandemic situation [6]. The learning medium that compatible to this situation is electronic learning (e-learning) media [25]. Because this kind of medium can send to the students although the distance between the teacher and the students is very far. So, recently research suggest to teacher to use innovation learning media that not only covers all the material that must understand by the students, but also easy to send and used by the students. This media also make students enjoy to study [6], [24] like the medium that used in this research.

Because all of the reason, the use of educational game that accompanied with e-module can increase students' learning motivation in experimental class more than the control class that just use Google Form as the learning medium. But, the existence of this medium does not replace the learning that organized by the teacher, because this medium only reinforces it [26].

\section{CONCLUSION}

Based on the result of the analysis and discussion above, it can be concluded that the use of android-base biology educational game with e-module during the 
COVID-19 pandemic can increase students' learning motivation better than using google form only. The students' learning motivation in experimental class which using educational game with e-module increase 14,05 , from 76,18 to 90,23 , while in the control class increase 7,41 , from 74,73 to 82,14 .

Base on the result, this research gives suggestion to the future research, that is to develop similar learning medium in the other subjects and then using it in learning process in order to increase students' learning motivation, especially in natural science subject.

\section{REFERENCES}

[1] C. Adhetya, I.D. Listiana, S.P.D. Larasati, Motivasi Belajar Siswa SMA Pada Pembelajaran Daring di Masa Pandemi Covid-19, Ilmu AlQur'an : Jurnal Pendidikan Islam 3 (2020) 123140. DOI: https://doi.org/10.37542/iq.v3i01.57

[2] M.H. Dembo, M.J. Eaton, School Learning and Motivation, G. D. Phye, Handbook of Academic Learning : Construction of Knowledge, 1997.

[3] M. Cheng, T. Su, W. Huang, J. Chen, What Do Students Learn and How Do They Perceive?, British Journal of Educational Technology 45(5) (2014) 820-833. DOI: https://doi.org/10.1111/bjet.12098

[4] A. Albadi, S.A. David, The Impact of Activity Based Learning on Students' Motivation and Academic Achievement: A Study Among 12 Th Grade Science and Environment Students in A Public School in Oman, Speacialty Journal of Knowledge Management 4(4) (2019) 44-53.

[5] A. G. C. Wicaksono, I. B. Minarti, F. Roshayanti, Analysis of Students' Science Motivation and Nature of Science Comprehension in Middle School, Jurnal Pendidikan Biologi Indonesia 4(1) (2018) 35.

DOI: https://doi.org/10.22219/jpbi.v4i1.5354

[6] Z. Zaharah, A. Susilowati, Meningkatkan Motivasi Belajar Peserta Didik dengan Menggunakan Media Modul Elektronik di Era Revolusi Industri 4.0, Biodik 6 (2020) 39-52. DOI: https://doi.org/10.22437/bio.v6i2.8950

[7] A.D. Kurniawan, N.D. Muldayanti, B.E. Putri, Developing Flash Media of Quranic-Based Human Reproduction System Material, Jurnal Pendidikan Biologi Indonesia 4 (2018) 235-242.
[8] A.M. Ortiz-Colón, J. Jordán, M. Agredal, Gamificación en educación: una panorámica sobre el estado de la cuestión, Education Pesquisa 44 (2018) 1-17. DOI: https://doi.org/10.1590/s1678463420184417377 $\underline{3}$

[9] B. Mulatsih, Penerapan Aplikasi Google Classroom, Google Form, dan Quizizz Dalam Pembelajaran Kimia Di Masa Pandemi Covid19, Ide Guru: Jurnal Karya Ilmiah Guru 5 (2020) $16-26$.

[10] S. Bulan, H.S. Zainiyati, Pembelajaran Online Berbasis Media Google Formulir dalam Tanggap Work from Home Masa Pandemi Covid-19 di Madrasah Ibtidaiyah Negeri (MIN) 1 Paser, Syamil: Jurnal Pendidikan Agama Islam 8 (2020) 15-34. DOI: https://doi.org/10.21093/sy.v8i1.2300

[11] A.P. Sekarini, Persepsi Peserta Didik dan Guru Ipa Terhadap Pengguaan Game Edukasi, Jurnal Pendidikan Sains dan Matematika 7 (2019) 3540.

[12] F. Najikhah, Keefektifan MPI Game Edukasi Terhadap Hasil Belajar IPA di Kelas 1 Sekolah Dasar, Indonesian Journal of Curriculum and Educational Technology Studies 4 (2016) 58-65.

[13] R.L. Rizalni, A. Trisnadoli, M.I. Zul, Pengembangan Game Edukasi Mobile Makhluk Hidup Kelas Reptilia Untuk Siswa SMP, Jurnal Nasional Pendidikan Teknik Informatika 8 (2) (2019) 87.8 DOI: https://doi.org/10.23887/janapati.v8i2.17880

[14] D.M. Pahlivi, H. Nurcahyo, The effect of android-based pictorial biology dictionary on students' motivation on topic of invertebrate, in: Journal of Physics: Conference Series, vol. 1241, IOP Publishing, Bristol, 2019. DOI: https://doi.org/10.1088/17426596/1241/1/01204 8

[15] L.M. Jeno, P.J.C. Adachi, J.A. Grytnes, V. Vandvik, E.L. Deci, The Effects of M-Learning on Motivation, Achievement and Well-Being: A Self-Determination Theory Approach, British Journal of Educational Technology 50(2) (2019) 669-683.

DOI: https://doi.org/10.1111/bjet.12657

[16] M.D. Insani, Studi Pendahuluan Identifikasi Kesulitan Dalam Pembelajaran Pada Guru IPA 
SMP Se-Kota Malang, Jurnal Pendidikan Biologi 7 (2016) 81-93.

[17] S.E. Renat, E. Novriyanti, Armen, Pengembangan Modul Dilengkapi Peta Konsep dan Gambar Pada Materi Keanekaragaman Makhluk Hidup Untuk Siswa Kelas VII SMP, Bioeducation Journal 1 (2017) 95-109.

[18] W.C. Lin, B.S. Jong, C.H. Lai, J.Y Ho, Mobile game-based learning to inspire students learning motivation, in: 2014 International Conference on Information Science, Electronics and Electrical Engineering (ISEEE), IEEE, Piscataway, New Jersey, 2014, pp. 1-4. DOI: https://doi.org/10.1109/InfoSEEE.2014.694777 $\underline{9}$

[19] M.G. Lodico, D.T. Spaulding, K.H. Voegtle, Methods in Educational Research: From Theory to Practice, Jossey-Bass, 2010.

[20] R. Huang, J.M. Spector, J. Yang, Educational Technology: A Primer for the 21st Century, Springer, 2019. DOI: https:/doi.org/10.1007/978-981-13-6643-7

[21] Y.C. Chen, Empirical Study on The Effect of Digital Game-Based Instruction on Students' Learning Motivation and Achievement, Eurasia Journal of Mathematics Science and Technology Education 13(7) (2017) 3177-3187. DOI: https://doi.org/10.12973/eurasia.2017.00711a

[22] T.F. Su, M.T. Cheng, S.H. Lin, Investigating The Effectiveness of An Educational Card Game for Learning How Human Immunology Is Regulated, CBE Life Sciences Education 13 (2014) 504-515.

[23] A.D. Puspitasari, Penerapan Media Pembelajaran Fisika Menggunakan Modul Cetak dan Modul Elektronik Pada Siswa SMA, Jurnal Pendidikan Fisika 7 (2019) 17-25.

[24] V.D. Soni, Global Impact of E-Learning During COVID-19, SSRN Electronic Journal (2020) 111. DOI: https://doi.org/10.2139/ssrn.3630073

[25] I.Z. Ichsan, H. Rahmayanti, A. Purwanto, D.V. Sigit, E. Kurniawan, A.K. Dewi, N. Wirdianti, F. M. Hermawati, G. Marhento, COVID-19 dan ELearning: Perubahan Strategi Pembelajaran Sains dan Lingkungan di SMP, Jurnal Inovasi Pembelajaran 6(1) (2020) 50-61. DOI: https://doi.org/10.22219/jinop.v6i1.11791
[26] E. Anggereini, Pengembangan E-Modul Pembelajaran Lingkungan Hidup Terintegrasi Nilai-Nilai Perilaku Pro Environmental Dengan Aplikasi 3D Pageflip Profesional Untuk Siswa SMA Sebagai Upaya Menjaga Lingkungan Hidup Berkelanjutan (Sustainable Environment), Biodik 3 (2017) 81-91. 